\title{
Exploring Affect Balance: Psychological Well-being of Church of England Clergy and Laity During the COVID-19 Pandemic
}

\author{
Andrew Village $^{1}$ (D) $\cdot$ Leslie J. Francis ${ }^{2}$
}

Accepted: 26 February 2021 / Published online: 17 March 2021

(c) The Author(s), under exclusive licence to Springer Science+Business Media, LLC, part of Springer Nature 2021

\begin{abstract}
Psychological well-being was assessed by affect balance (a function of negative and positive affect) during the first COVID-19 lockdown in 2020 among 4449 clergy and laity in the Church of England. Better well-being was promoted by preference for feeling over thinking in the psychological type judging process, being older, belonging to the Evangelical wing of the Church, and living in rural areas. Psychological well-being was lowered among people with a general tendency toward neuroticism, among those with an Epimethean (Sensing-Judging: SJ) psychological temperament, among Anglo-Catholics, among those living in inner cities, among clergy, and among those living with children under 13. The mitigating effects of relevant support were evident for both clergy and lay people. A key finding was that it was those sources of support that were least often rated highly that may have had the strongest positive effects on well-being, particularly on those groups where well-being was lowest.
\end{abstract}

Keywords Balanced affect · COVID-19 · Neuroticism · Psychological type · Religion · Support · Temperament

\section{Introduction}

The COVID-19 coronavirus pandemic of 2020 resulted in social upheaval in England on a scale not witnessed for several generations. Psychologists suggested research priorities during and after the pandemic needed to recognise the inequalities related to, among other things, mental health and levels of support (O'Connor

Andrew Village

a.village@yorksj.ac.uk

1 School of Humanities, York St John University, Lord Mayor's Walk, York YO31 7EX, UK

2 Centre for Educational Development, Appraisal and Research, University of Warwick, Coventry, UK 
et al. 2020a, b). The same authors identified better understanding of coping mechanisms as a key goal for research. The enforced lockdowns of society created widespread concern about the psychological well-being of large sections of the population (Marshall et al. 2020; Mental Health Foundation 2020). The Office for National Statistics found that just under half the population of Great Britain reported their well-being had been adversely affected by the pandemic (ONS 2020), a figure rising to around $80 \%$ for those who had previously experienced depression or anxiety. The concern for mental health in lockdown led to a number of studies in the general population that tried to assess changes in the levels of well-being during the first year of the pandemic (Groarke et al. 2020; O'Connor et al. 2020a, b; White and Van Der Boor 2020). More detailed studies based on interviews or focus groups began to emerge during 2020 which suggested that physical and social isolation, along with economic losses, contributed to reduced motivation, and lower psychological wellbeing (Williams et al. 2020).

Religious adherents were not immune from these effects, and indeed religious beliefs or practices might have caused some spread of the virus in particular instances (Dein et al. 2020). Religious coping may have helped some groups to weather the pandemic more successfully (Counted et al. 2020; Pirutinsky et al. 2020; Thomas and Barbato 2020), but religious organisations were nonetheless aware of the dangers for their members and the need to offer heightened support. The Church of England issued general guidance (Church of England 2020a), and guidance to clergy and lay ministers in particular (Church of England 2020b), but there was little evidence when lockdown began to show who was most at risk and what factors tended to promote or threaten well-being in this denomination. This paper reports on data from a large sample of clergy and lay people from the Church of England who completed an online survey from May to July 2020, during the height of the first lockdown in England. The survey contained items assessing perceived changes in positive and negative affect resulting from the lockdown, as well as a range of predictor variables related to individual differences, faith expression, context, and levels of support. We have previously reported on well-being among stipendiary clergy in this sample (Village and Francis, In press-b); this paper extends that analysis also to include other ministers and lay people, and to assess the effects of personality alongside church tradition, location, ordained status, and household context.

\section{The Lockdown of the Church of England}

The UK Government imposed a lockdown in response to the COVID-19 virus outbreak on 23 March 2020. Although the rules permitted access to religious buildings for private prayer, on the following day, the Church of England closed all its churches completely, to both clergy and lay people (McGowan 2020). Church of England adherents, along with those of other denominations were suddenly deprived of their main avenues of religious expression. Although online worship soon began to replace worship in churches, the loss of shared rituals and direct contacts with fellow congregants is likely to have added to a sense of isolation. As with the general population, vulnerable adults (those with reduced immune responses or the very 
elderly) were advised to self-isolate and avoid all contact beyond the people with whom they were already living. Younger adults of working age were threatened with the loss of their jobs, and many had to work at home. Schools were closed, so parents also became responsible for looking after school-aged children at home during school-times for several months, with many trying to also help them with their online studies.

Across the denomination, particular groups might have experienced the lockdown in different ways. Clergy and lay ministers needed to find new ways of maintaining worship and pastoral ministry, and those without access to IT expertise may have worried about how to serve their congregations. Those who particularly valued church buildings as sacred spaces, such as Anglo-Catholics, would have felt the closure harder than others (Village and Francis, In press-a) while the change in the pace of life seemed to be more evident in the centre of large cities than in more rural areas. Part of the aim of this study is to provide evidence about where in the Church of England the effects of lockdown may have been perceived as hardest.

\section{Psychological Predispositions and Well-being in Lockdown}

The ONS surveys showed that those people most likely to suffer from depression or anxiety were most likely to report declines in well-being during lockdown. It seems reasonable to suggest that the dispositions associated with neuroticism, as defined by the Eysenck three-dimensional model of personality (Eysenck and Eysenck 1985; Eysenck et al. 1985), might predict declines in well-being during lockdown. The underlying assumption posited by Eysenck was that those who score high on neuroticism have a low activation threshold in those parts of the brain related to the fightor-flight response (Furnham et al. 2008). This means they tend to respond strongly to stressors, showing frequent signs of negative affect such as anxiety or fear. Other indications of neuroticism include mood swings, feelings of guilt and a tendency toward depression. One aim of this paper was to test if churchgoers who showed a general tendency toward neuroticism were also more likely to report decreased wellbeing as a result of lockdown.

Eysenck's model of personality arose from an interest in abnormal psychology, so it would hardly be surprising if there was a relationship with psychological well-being during lockdown. In contrast, Jung's model of psychological type is based on components of normal psychological function (Jung 1971), and it may be more useful to understand how these relate to well-being during times of crisis such as a pandemic. Jung's model was developed into four components, each with two modes of expression: orientation (extraversion, E, and introversion, I), perceiving (sensing, S, and intuition, $\mathrm{N}$ ), judging (thinking, T, and feeling, F), and attitude toward the outer world (judging, $\mathrm{J}$, and perceiving, $\mathrm{P}$ ). The type model has been operationalised by a range of instruments such as the Myers-Briggs Type Indicator, MBTI®, (Myers et al. 1998), the Keirsey Temperament Sorter, KTS, (Keirsey 1998; Keirsey and Bates 1978), and the Francis Psychological Type Scales, FPTS, (Francis 2005). The latter were developed specifically as a research tool, scoring preferences in each dimension on a scale of 1 to 10. Studies have shown that psychological type scores tend to correlate with those for 
conceptually similar traits in other models such as Eysenck's three dimensions (orientation with extraversion-introversion) (Francis and Jones 2000; Furnham et al. 2001; Steele and Kelly 1976) and the Big Five (orientation with extraversion-introversion, perceiving with openness to experience, judging with agreeableness, and attitude to the outer world with conscientiousness) (Furnham 1996; McCrae and Costa 1989).

The characteristics associated with various aspects of the psychological type model might predispose individuals to better or worse coping during a pandemic lockdown. The obvious link raised early in the pandemic by many commentators in the UK and elsewhere (Denham 2020; Kluth 2020; Schultz 2020), is that introverts might fare better than extraverts in a situation where social discourse seems to be drastically curtailed. Extraverts may be de-energised by enforced solitude, whereas introverts might enjoy it. Other aspects of the model might also be important in a time of disruption. Temperament theory builds on psychological type by positing four profiles or temperaments (Keirsey and Bates 1978). One such profile, the Epimethean or SJ temperament, refers to sensing types who prefer judging in the outer world. The Epimethean temperament characterises people who tend to be dutiful and who are the 'guardians' of institutions and familiar social structures. This temperament is the most frequent in Church of England congregations (Francis et al. 2011a) and their profile suggests that they may find the sudden loss of their familiar and routine access to religious institutions, such as church buildings and church services, a particularly disorientating experience. The judging dimension (thinking versus feeling) might also influence psychological wellbeing if feeling types, who tend to base decisions subjectively on shared values and empathetic understanding, found it easier to connect to others when normal patterns of life were disrupted than did thinking types, who tend to base decisions objectively on logic, evidence, and principles.

\section{Support and Well-being in Lockdown}

One way of overcoming the adverse effects of lockdown was to seek support from others: this was part of the advice given within the Church of England and featured widely in advice from government (Public Health England 2020) and mental health agencies (Mind 2020). Social support has been shown to offset the effects of burnout in caring professions (Ruisoto et al. 2021), including during the COVID-19 pandemic (Hou et al. 2020), and has also been shown to be generally beneficial for clergy well-being in the Church of England (Francis et al. 2018). Stipendiary parochial clergy in the Coronavirus, Church \& You survey who felt well supported also showed less adverse change in stress or negative affect during lockdown (Village and Francis, In press-b). Here, we extend this latter analysis by applying it to lay people as well as to clergy. The aim was to identify the most effective sources of support for those receiving or giving ministry during lockdown.

\section{Affect Balance as a Measure of Psychological Well-being}

The balanced affect model of psychological well-being (Bradburn 1969) conceptualises positive and negative affect as two separate continua, and well-being 
as the function of these two entities. Individuals with high negative affect might still experience generally good well-being if they also have high levels of positive affect. This idea has been tested among clergy using the Francis Burnout Inventory (FBI), which has two scales measuring emotional exhaustion in ministry and satisfaction in ministry (Francis et al., 2005a). Studies of several different samples of clergy have shown that the tendency to burnout, which is promoted by emotional exhaustion, is mitigated among those clergy who report greater satisfaction in their ministries (Francis et al. 2011a; Village et al. 2018). In this study, we wanted to assess changes in well-being as a result of the lockdown among both clergy and laity, so it was necessary to devise a different scale to estimate affect balance, the difference between negative and positive affect. The scale development and properties are reported elsewhere (Francis and Village, Under review); here, we use the two components of the scale, positive and negative affect, to create a measure of 'affect balance', which we use as a proxy measure of how individuals perceive changes in psychological well-being during the lockdown.

\section{Method}

\section{Procedure}

The Coronavirus, Church \& You online survey was developed during April 2020 and launched on the Qualtrics XM Platform on 8 May, when the UK had been in lockdown for over a month. A link to the survey was distributed through the online and paper versions of the Church Times, the main newspaper of the Church of England, as well as through Church of England dioceses and other denominations, including Baptists and Methodists. The survey closed on 23 July, by which time there were over 7000 replies, 5347 of which were from respondents affiliated with the Church of England. Of these, 4449 had sufficiently complete responses to be used in this analysis.

\section{Sample Profile}

The sample profile (Table 1) was similar to other surveys of the Church of England where data were collected through the Church Times (Francis et al. 2005b; Village 2018). Although not wholly representative of the Church at large, it did include good proportions of clergy $(29 \%)$ and lay people $(71 \%)$, men $(40 \%)$ and women $(60 \%)$, and those from the three main church traditions. There was probably an oversampling of clergy, and an underrepresentation of younger adults and Evangelicals, which reflects the readership of the newspaper. Despite this, the sample did include a wide spectrum of members of the Church of England and was the largest singlestudy sample of the denomination collected during the first lockdown. 
Table 1 Profile of Church of England participants in the survey

\begin{tabular}{|c|c|c|}
\hline & & $\%$ \\
\hline \multirow[t]{2}{*}{ Sex } & Female & 60.4 \\
\hline & Male & 39.6 \\
\hline \multirow[t]{7}{*}{ Age } & $20 \mathrm{~s}$ & 2.9 \\
\hline & $30 \mathrm{~s}$ & 6.2 \\
\hline & $40 \mathrm{~s}$ & 13.0 \\
\hline & $50 \mathrm{~s}$ & 21.3 \\
\hline & $60 \mathrm{~s}$ & 29.3 \\
\hline & $70 \mathrm{~s}$ & 22.8 \\
\hline & $80 \mathrm{~s}+$ & 4.5 \\
\hline \multirow[t]{3}{*}{ Tradition } & Anglo-Catholic & 29.3 \\
\hline & Broad Church & 52.0 \\
\hline & Evangelical & 18.8 \\
\hline \multirow[t]{3}{*}{ Location } & Rural & 35.9 \\
\hline & Town/suburb & 54.9 \\
\hline & Inner city & 9.2 \\
\hline \multirow[t]{2}{*}{ Ordained } & Laity & 70.6 \\
\hline & Clergy & 29.4 \\
\hline Others in & Live alone & 14.8 \\
\hline \multirow[t]{5}{*}{ Household } & Children $(<13)$ & 11.0 \\
\hline & Teenagers & 10.5 \\
\hline & Other adults & 84.1 \\
\hline & Had virus & 3.3 \\
\hline & Self-isolated & 33.1 \\
\hline
\end{tabular}

$N=4449$

\section{Instruments}

\section{Psychological Well-being}

Affect balance was used as proxy measure of overall well-being. It was based on two five-item scales that examined changes in Positive Affect, PA, (Happiness, Excitement, Thankfulness, Hopefulness, and Trust) and Negative Affect, NA, (Exhaustion, Anxiety, Stress, Fatigue, and Frustration) since the lockdown began (Francis and Village, Under review). Each item had a three-point response (decrease, no change, increase) and was scored so that high scores indicated high increases in levels of Positive or Negative Affect. The scales had good internal reliability as measured by Cronbach's alpha (PA=.70, NA =.83), and the difference between scores (PA minus NA) gave an indication of 'affect balance', an overall measure of changes in psychological well-being. Average affect scores were similar [PA: mean (SD) $=10.41$ (2.04); NA: mean $(\mathrm{SD})=10.99$ (2.78)], so the difference ranged from minus to plus ten, with a mean near zero. For ease of interpretability, ten was added to scores, 
to produce the final affect balance variable, which was normally distributed [mean $(\mathrm{SD})=9.42$ (4.23), range 5-15, skewness $=0.18$, kurtosis $=-0.39]$. In this analysis, larger scores were taken as indicating greater increases in positive than negative affect, and therefore better well-being.

\section{Individual Differences}

Neuroticism was assessed using the six-item scale from the abbreviated version of the revised Eysenck Personality Questionnaire, EPQR-A, (Francis et al. 1992). This instrument uses yes/no answers to items such as 'Would you call yourself a nervous person?' and is a measure of general emotional instability, with high scores indicating a tendency to anxiety, mood swings and worry. In this sample, the scale had good internal reliability $(\alpha=.77)$.

Psychological type preferences were assessed using the Francis Psychological Type Scales (FPTS). This is a 40-item instrument comprising four sets of ten forcedchoice items related to each of the four components of psychological type: orientation (extraversion or introversion), perceiving process (sensing or intuition), judging process (thinking or feeling), and attitude toward the outer world (judging or perceiving) (Francis 2005; Village, In press). Previous studies have demonstrated that this instrument functions well in a range of church-related contexts (for example, see Francis et al. 2007, 2020; Francis et al. 2011a, b; Village 2016). In this sample, the alpha reliabilities were .83 for the EI scale, .75 for the SN scale, .73 for the TF scale, and .71 for the JP scale. Based on a priori theory, we tested three variables related to psychological type: scores for extraversion and feeling, and a dummy variable identifying the SJ temperament. These three independent measures related to the most likely aspects of psychological type that would predict well-being during lockdown.

Other individual-difference variables were sex $(0=$ male, $1=$ female) and age (by decade, treated as continuous variable).

\section{Religious Orientation}

Church tradition was assessed using a 7-point bipolar scale labelled 'Anglo-Catholic' at one end and 'Evangelical' at the other. It has been shown to predict well a wide range of differences in belief and practice in the church of England (Randall 2005; Village 2012b) and was used to identify Anglo-Catholic (scoring 1-2), Broad Church (3-5) and Evangelical (6-7) respondents. Anglo-Catholic and Evangelical were used as dummy variables in the regression analyses.

\section{Contextual Variables}

Location was measured by a single item with three responses: 'rural', 'town/suburb', and 'inner city'. The first and last categories were used as dummy variables in regression analyses. Ordination status was considered a proxy for different roles and status within the church context $(1=$ clergy, $0=$ laity $)$. Respondents were also asked 
how many others lived in their household and we used the number of children under 13 years old as a measure of likely parenting pressures during lockdown. The survey also included questions related to experiences of the virus itself: whether someone had definitely had the virus and whether they had to self-isolate for other reasons. These two variables were included in initial analyses but excluded from the regressions as they showed no correlation with affect balance.

\section{Sources of Support}

Perceived level of support was assessed by two sets of items listing various possible sources of support, one designed for those who received ministry and one for those who gave ministry during lockdown. The two groups were not the same as laity versus clergy, because some retired clergy did not minister during lockdown, and the Church of England has a large number of lay ministers. Clergy comprised $6 \%$ of 2567 who received ministry and $61 \%$ of 1882 who gave ministry. Items were presented in a grid and participants were asked to tick an answer only for those sources of support that they used during lockdown because not all sources (such as medical or social services) would be applicable to everyone. Each item had three levels of support: 'none', 'some', and 'well supported', which were scored 1-3 and treated as ordinal variables. In this analysis, the sources for those receiving ministry were household, family elsewhere, friends, neighbours, local clergy, local congregation, your diocese, and the Church nationally. The sources for those giving ministry were household, ministry team, congregation, IT experts, members of the public, your diocese, your bishop, and the Church nationally. For each set of participants, only those for whom all sources were applicable were included in the sample, which amounted to 1605 (63\%) of those receiving ministry, and $1139(61 \%)$ of those giving ministry. This allowed a fairer comparison of the relative efficacy of sources of support.

\section{Analysis}

The first stage of analysis was to use bivariate correlation on the whole sample to explore how affect balance varied with the predictor variables and the extent to which predictor variables were correlated among themselves. The second stage was to use hierarchical linear regression to test the effects of predictors after allowing for others in the model. The rationale behind the nested models was to enter variables related to individual differences in the first three models (sex, age, and personality variables), then those related to religious expression (church tradition), and finally those related to context and role (rural, inner city, ordination status, and children). The third stage of analysis used the two subsets of the sample to explore the relationship between perceived support and affect balance. The aim was to identity sources of support that seemed most important in promoting psychological well-being. For each group (receiving and giving ministry) bivariate correlations were based on Spearman's rank test because the support data were ordinal. Multiple regression was 
then used to identify the sources of support than were significant predictors of affect balance after allowing for the effects of all other sources.

\section{Results}

\section{Predictors of Affect Balance}

Affect balance was correlated with 11 of the 13 predictor variables (Table 2). The exceptions were sex and ordination status. As might be expected, the strongest correlation was a negative relationship with neuroticism $(r=-.34, p<.001)$, suggesting those who generally suffered from emotional lability showed the poorest wellbeing outcomes during lockdown. There was a positive correlation with age $(r=.18$, $p<.001$ ), suggesting older people found life easier during lockdown, despite being more susceptible to harm if they did catch the virus. Predictor variables were correlated among themselves in ways that might be expected from previous studies. For example, the higher preference for feeling over thinking among women compared to men is a widespread phenomenon (Kendall 1998; Myers et al. 1998) and was evident in this sample $(r=.18, p<.001)$. Other correlations probably reflected structural patterns in the Church, such as the higher proportion of women among the laity compared with the clergy, the young age profile of Evangelicals, and the tendency for Anglo-Catholic churches to be in towns or cities more than in the countryside. The correlations suggested that multiple regression was necessary to identify the main effect of predictor variables after controlling for other factors.

Multiple regression identified those predictors where confounding may have masked or exaggerated independent effects on affect balance (Table 3). The strongest and most consistent effects were those of age (older people had higher affect balance), the negative effect of neuroticism, and the positive effect of feeling scores. The correlation with sex was small and reached significance only when controlling for neuroticism (model 3), and it was weakened by adding contextual variables (model 5). Extraversion was positively correlated with affect balance, but this effect disappeared when the Eysenck neuroticism scores were added (model 3), which might be because the FPTS extraversion scale measures stable extraversion. The SJ temperament was not correlated with well-being when controlling for age and sex (model 2), but a weak negative correlation was present in model 5, which emerge when controlling for ordination status. The different proportions of SJs among clergy and laity may have masked this effect in the overall sample. It was in the expected direction, with SJs reporting slightly lower affect balance than the rest of the sample.

Religious expression and contextual variables were all significant predictors of affect balance, after allowing for individual differences and other variables in the model. Anglo-Catholics had lower scores, and Evangelicals higher scores, compared with others in the sample. Those living in rural areas had higher scores, and those in inner cities lower scores, compared with others in the sample. Clergy had lower 


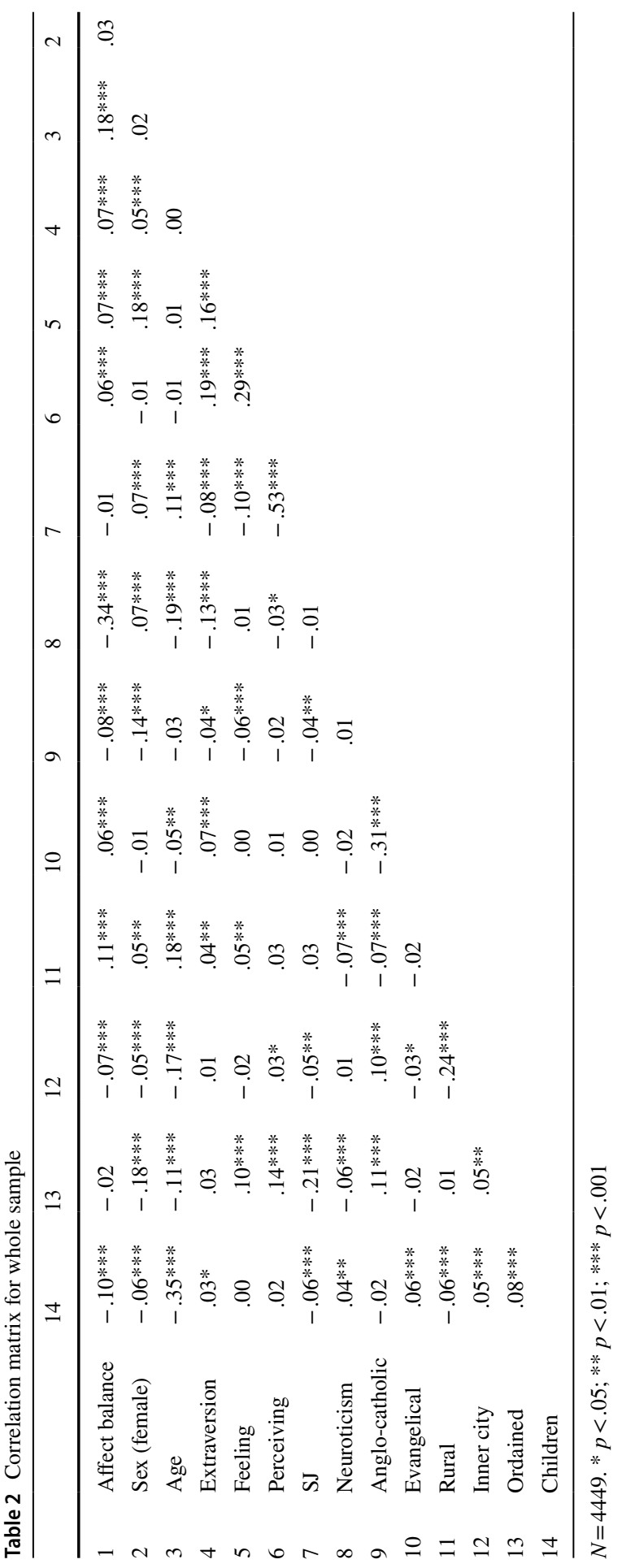


Table 3 Hierarchical linear regression of affect balance

\begin{tabular}{|c|c|c|c|c|c|}
\hline & \multicolumn{5}{|l|}{ Model } \\
\hline & 1 & 2 & 3 & 4 & 5 \\
\hline & $\beta$ & $\beta$ & $\beta$ & $\beta$ & $\beta$ \\
\hline Sex (female) & .03 & .01 & $.04 * *$ & $.03 *$ & .02 \\
\hline Age & $.18 * * *$ & $.18 * * *$ & $.12 * * *$ & $.12 * * *$ & $.09 * * *$ \\
\hline Extraversion & & $.06 * * *$ & .02 & .01 & .01 \\
\hline Feeling & & $.06^{* *}$ & $.06^{* * *}$ & $.06^{* * *}$ & $.06 * * *$ \\
\hline SJ temperament & & -.02 & -.02 & -.03 & $-.03 *$ \\
\hline Eysenck neuroticism & & & $-.32 * * *$ & $-.32 * * *$ & $-.32 * * *$ \\
\hline Anglo-catholic & & & & $-.05 * * *$ & $-.05^{* *}$ \\
\hline Evangelical & & & & $.04 * *$ & $.05 * *$ \\
\hline Rural & & & & & $.06 * * *$ \\
\hline Inner city & & & & & $-.03^{*}$ \\
\hline Ordained & & & & & $-.03^{*}$ \\
\hline Children & & & & & $-.04 * *$ \\
\hline$R^{2}$ & .03 & .04 & .13 & .14 & .15 \\
\hline$\Delta R^{2}$ & $.03 * * *$ & $.01 * * *$ & $.10 * * *$ & $.01 * * *$ & $.01 * * *$ \\
\hline
\end{tabular}

$N=4449 . * p<.05 ; * * p<.01 ; * * * p<.001 . \beta=$ Standardised beta weight

scores than laity after controlling for all other variables in the analysis. Those with children in their household had lower scores than others in the sample.

\section{Effects of Support on Affect Balance}

For those receiving ministry (mostly lay people), levels of perceived support from nearly all sources were positively correlated (Table 4). The only exception was between household and national church. This suggests that there was an underlying tendency for some individuals generally to feel better supported than others, though the correlations were not so large as to suggest this was simply response bias because individuals ticked all responses in the same column. The proportion that reported they were well supported varied considerably between sources (Table 5), with those referring to family and friends rated higher, on average, than local support such as neighbours, clergy, or congregation, which in turn rated higher than more distanced church support such as the diocese or the Church nationally. Levels of support from all sources were significantly positively correlated with affect balance in the bivariate analysis, but multiple regression (Table 5) suggested the key sources were household, friends, neighbours, and the Church nationally. It seemed that it was not necessarily sources with the highest reported levels of support that were most crucial in promoting well-being. Only 36\% felt well-supported by neighbours (compared with $78 \%$ by households), yet this was the best predictor of positive 
Table 4 Correlation matrix of sources of support for those receiving ministry

\begin{tabular}{|c|c|c|c|c|c|c|c|c|c|}
\hline & & 9 & 8 & 7 & 6 & 5 & 4 & 3 & 2 \\
\hline 1 & Affect balance & $.14 * * *$ & $.12^{* * * *}$ & $.12 * * *$ & $.10 * * *$ & $.19 * * *$ & $.17 * * *$ & $.15^{* * *}$ & $.14 * * *$ \\
\hline 2 & Household & .04 & $.07 * * *$ & $.12 * * *$ & $.09 * * *$ & $.16^{* * * *}$ & $.16^{* * * *}$ & $.26 * * *$ & \\
\hline 3 & Family elsewhere & $.11 * * *$ & $.14 * * *$ & $.21 * * *$ & $.15^{* * * *}$ & $.32 * * *$ & $.47 * * *$ & & \\
\hline 4 & Friends & $.11 * * *$ & $.12 * * *$ & $.33 * * *$ & $.18 * * *$ & $.49 * * *$ & & & \\
\hline 5 & Neighbours & $.07 * *$ & $.15^{* * *}$ & $.25 * * *$ & $.17 * * *$ & & & & \\
\hline 6 & Local clergy & $.30 * * *$ & $.36^{* * *}$ & $.53 * * *$ & & & & & \\
\hline 7 & Local congregation & $.28 * * *$ & $.31 * * *$ & & & & & & \\
\hline 8 & Diocese & $.53 * * *$ & & & & & & & \\
\hline 9 & Church nationally & & & & & & & & \\
\hline
\end{tabular}

Table 5 Multiple regression of affect balance against sources of support for those receiving ministry

\begin{tabular}{lclll}
\hline Source of support: & \multicolumn{4}{l}{ Support level } \\
\cline { 2 - 5 } & None & Some & Well & $\beta$ \\
& $\%$ & $\%$ & $\%$ & \\
\hline Household & 9 & 13 & 78 & $.08^{* *}$ \\
Family elsewhere & 13 & 36 & 51 & .04 \\
Friends & 6 & 46 & 49 & $.07^{*}$ \\
Neighbours & 23 & 42 & 36 & $.12^{* * *}$ \\
Local clergy & 25 & 40 & 35 & .03 \\
Local congregation & 16 & 45 & 39 & .00 \\
Diocese & 54 & 34 & 12 & .03 \\
Church nationally & 47 & 42 & 11 & $.10^{* *}$ \\
\hline
\end{tabular}

$N=1605 . * p<.05 ; * * p<.01 ; * * * p<.001 ; \beta=$ Standardised beta weight for regression with affect balance

affect balance. Similarly, only $11 \%$ felt well-supported by the Church nationally, yet it was the second-best predictor of well-being.

The neighbour effect prompted us to see if this was stronger for older people than younger ones. A persistent narrative during the lockdown was that it was the elderly housebound who would benefit most from neighbourly support. There was a highly statistically significant neighbours-age interaction effect, but this indicated, surprisingly, that it was among younger adults that affect balance was most strongly influenced by neighbour support, with little effect in the oldest age group (Fig. 1). The age group that had the lowest levels of well-being benefited the most from good neighbours.

The results for those giving ministry (mostly clergy) paralleled those above, though the sources of support where slightly different. All sources were significantly correlated with each other and with affect balance (Table 6). The sources that were rated most highly were again those closer to home (household, ministry 


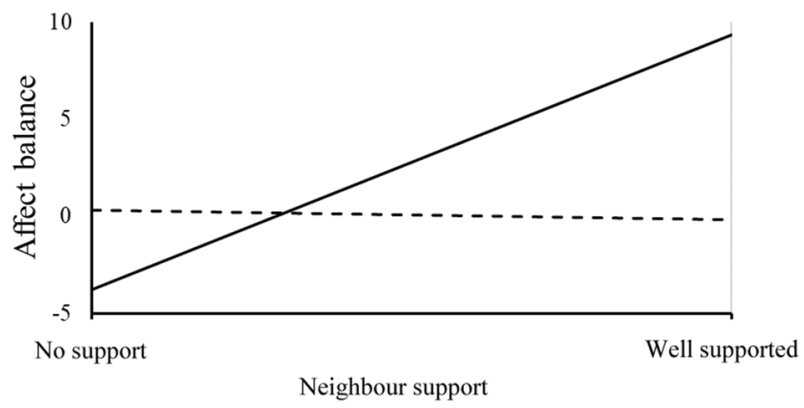

Fig. 1 Interaction effect of age with level of support from neighbours on levels of affect balance among those receiving ministry. Lines show correlation of affect balance on age for those in their $20 \mathrm{~s}$ (solid line) and those in their $80 \mathrm{~s}$ (broken line)

team, congregation), while those rated lowest were public and the Church nationally (Table 7). Once again, it was the lowest rated that were among the most important for predicting higher affect balance scores. For those ministering, perceiving support from the public, household, national Church, and ministry team were all significant independent predictors of higher affect balance.

\section{Discussion}

This study of a large sample of committed religious people from the Church of England has revealed important and original information about the factors that influenced psychological well-being during an unprecedented time of social and religious upheaval. There were several key findings that might inform how the psychological harms of such events could be addressed in the future.

First, the balanced affect model of psychological well-being can be usefully applied to both clergy and lay people. Previous use of this model has concentrated

Table 6 Correlation matrix of sources of support for those giving ministry

\begin{tabular}{|c|c|c|c|c|c|c|c|c|c|}
\hline & & 9 & 8 & 7 & 6 & 5 & 4 & 3 & 2 \\
\hline 1 & Affect balance & $.20 * * *$ & $.15 * * *$ & $.15^{* * * *}$ & $.14 * * *$ & $.22 * * *$ & $.14 * * *$ & $.19 * * *$ & $.17 * * *$ \\
\hline 2 & Household & $.08 * *$ & $.16 * * *$ & $.14 * * *$ & $.14 * * *$ & $.16^{* * * *}$ & $.24 * * *$ & $.23 * * *$ & \\
\hline 3 & Ministry team & $.28 * * *$ & $.29 * * *$ & $.30 * * *$ & $.33 * * *$ & $.26 * * *$ & $.51 * * *$ & & \\
\hline 4 & Congregation & $.21 * * *$ & $.24 * * *$ & $.25 * * *$ & $.28 * * *$ & $.48 * * *$ & & & \\
\hline 5 & Public & $.25 * * *$ & $.23 * * *$ & $.24 * * *$ & $.21 * * *$ & & & & \\
\hline 6 & IT experts & $.27 * * *$ & $.23 * * *$ & $.26^{* * * *}$ & & & & & \\
\hline 7 & Diocese & $.55 * * *$ & $.79 * * *$ & & & & & & \\
\hline 8 & Bishop & $.54 * * *$ & & & & & & & \\
\hline 9 & Church nationally & & & & & & & & \\
\hline
\end{tabular}

$N=1139$. For explanation, see Table 4 
Table 7 Multiple regression of affect balance against sources of support for those giving ministry

\begin{tabular}{lcccc}
\hline Source of support: & \multicolumn{3}{l}{ Support level } & \\
\cline { 2 - 5 } & None & Some & Well & $\beta$ \\
& $\%$ & $\%$ & $\%$ & \\
\hline Household & 3 & 15 & 82 & $.12^{* *}$ \\
Ministry team & 7 & 36 & 57 & $.09^{*}$ \\
Congregation & 8 & 46 & 46 & -.03 \\
IT experts & 24 & 41 & 35 & .04 \\
Public & 31 & 44 & 25 & $.15^{* * *}$ \\
Diocese & 14 & 51 & 35 & .00 \\
Bishop & 18 & 45 & 38 & .02 \\
Church nationally & 24 & 52 & 24 & $.10^{* *}$ \\
\hline
\end{tabular}

$N=1139$. For explanation, see Table 5

on clergy burnout to demonstrate the way that the positive affect experienced by ministry service can counter some of the negative affect arising from the emotional strain that often accompanies this kind of professional service (Francis et al. 2015, 2011b; Village et al. 2018). The main instrument used in these studies, the Francis Burnout Inventory, was specifically designed for in-service clergy and has items related to religious ministry. In this study, there was a need to design an instrument that would work equally well with those giving and receiving ministry, and which could assess recent changes in affect at one point in time. The usefulness of the instrument in identifying the operation of balanced affect on overall coping with the lockdown has been demonstrated elsewhere (Francis and Village, Under review). Here, we demonstrate that the affect balance indicated by such an instrument can identify the factors that are most likely to militate or mitigate poor psychological well-being during a sudden adverse event. This instrument, or an adaptation of it, could be usefully applied in a range of contexts, with perhaps the particular content of PA or NA items adjusted to circumstances.

Second, the study shows how individual differences may predispose clergy or laity to cope well or poorly with such a crisis. The main predictor was, not surprisingly, a person's general emotional disposition, with high neuroticism scores being the best single predictor of poor psychological well-being during the lockdown. Mental health was widely recognised as a major issue in the UK and elsewhere during the lockdown, and simple instruments that measure emotional temperament could help individuals have better self-awareness of their susceptibility to poor well-being in a crisis. There were other personality factors that influenced wellbeing, notably preferences in the psychological-type judging process. People with a preference for feeling rather than thinking tended to have better well-being, and the reverse was true for those preferred thinking to feeling. Feeling types have a natural empathy and ability to harmonise with others, and this may have made it easier both to give and to receive emotional comfort when communication was disrupted. Thinking types may have found a time when the nation needed to pull together and display shared values and commitments more difficult, especially if the restrictions 
were not always logical or based on the best evidence. The feeling-thinking preference is partly linked to sex, but sex in this instance was not as strong a predictor of well-being as was this personality preference.

Another, weaker, effect was that those with the SJ temperament reported lower well-being. Even with a large sample, the effect was difficult to isolate and was masked by other variables, but in the expected direction. Because the SJ temperament is one that prizes the routine, familiar and structured, SJs may have been more sensitive to the loss of normal routines that other temperaments.

Another, rather unexpected, finding related to individual differences was that extraverts appeared, at first glance, to have higher levels of affect balance than did introverts. Several commentators suggested that it might be introverts who would thrive better in the isolated conditions of lockdown, whereas extraverts might miss the social contacts that energise them (Berg 2020; Denham 2020; Duffy 2020). The analysis here revealed that the association of extraversion with higher well-being may have been because the extraverts in the sample tended to be more emotionally stable than the introverts. Controlling for neuroticism removed the effect, and it seemed that neither of the two orientations to the outer world was strongly related to psychological well-being during the lockdown. This ambiguity in the relationship of extraversion-introversion to well-being in lockdown has emerged in other studies (Travers 2020; Wei 2020), and among some commentators as the lockdown pandemic wore on (Alford 2020; Singh 2020), which suggests that both orientations may find positive and negative aspects to the lockdown experience. One Church of England cleric has noted that his working desk, normally the place where he was relaxed as an introvert, had become a more draining place to be:

As a result, my desk feels like a dramatically different place. It is no longer a location reserved for bounded, secluded time on emails, the phone, or sermon writing. Rather, my desk is now a meeting-room, a supervision site, the coffee queue at the back of church, and a worship space. (Lockley 2020)

Third, there was a marked tendency for younger people to have lower well-being than older people during the lockdown. Age may reflect both individual difference (if well-being is related to age per se) or context (as a proxy for the different kinds of lifestyle under lockdown). The sample reflected the generally ageing profile of the Church of England, and a high proportion of respondents were at or near retirement age. Although this age group were more vulnerable to the physical effects of the virus, they may have been relatively less affected by the social dislocation of lockdown. It was young people whose incomes were most threatened and who were more likely to have to try and keep working in conditions that could be stressful, especially if it meant being confined to home with young children.

Fourth, the study showed that Anglo-Catholics tended to fare worse than Evangelicals during the lockdown. Elsewhere we have shown that Anglo-Catholics in the Church of England, in common with Roman Catholics, had stronger ties to church buildings than did Anglican Evangelicals (Village and Francis, In press-a). Lockdown also meant that the Eucharist, a rite that is more central to Anglo-Catholics than Evangelicals, was not available for the vast majority of the Church, and this 
may have made the online worship that was available less spiritually satisfying to those with more Catholic leanings.

Fifth, the study showed that contextual variables had some predictive power after allowing for individual differences and religious expression. People in rural areas tended to fare better than those in inner city areas. In the first lockdown in England, it was places such as London where the virus spread most rapidly, and where the shutting down of places of work had the most startling effect. Inner cities became ghost towns, and people used to a vibrant social atmosphere would have been very aware of the change in the pace of life. Perhaps in rural areas, with more scattered communities and higher isolation in normal times, the effect of lockdown was less obvious, and this may have meant people perceived less change in PA or NA. Clergy seemed to have poorer psychological well-being than did lay people. We have shown elsewhere the particular effect of stress on clergy in this sample (Village and Francis, In press-b); and in this sample, it was parochial clergy in their fifties and sixties who had the highest levels of stress. These are key people on whom the responsibility of trying to maintain some sort of ministry would most heavily rest. The data suggest that after allowing for the different age, sex, and psychological profiles of clergy, it was this role in particular that made some vulnerable to poor levels of affect balance. The detrimental effects on well-being of those trying to cope with childcare in lockdown, when schools were closed, emerged as those with children under 13 had lower well-being than others in the sample, after allowing for the fact this was partly related to age.

Sixth, the effects of support emerged as crucial for both for those receiving ministry and those giving ministry. We have reported elsewhere on the mitigating effects of support on clergy in this study, and this paper reinforces those findings using a different measure of well-being. Here, we also show that support for those receiving ministry (overwhelmingly lay people) was also important and that, crucially, it was those sources where support was looked for but less often perceived as forthcoming that were nonetheless most powerful in making a difference. Nearly, all lay people reported receiving some support from their households (91\%), but fewer sensed they had any support from neighbours $(77 \%)$ or the Church at a national level $(43 \%)$. Where people reported that they were well supported from these latter two sources, however, they also tended to report high levels of psychological well-being. The greater effect of neighbourly support on well-being among young rather than old adults was important evidence that common wisdom does not always make the best evidence on which to base action.

\section{Limitations of the Study}

The study was based on a large convenience sample, and it was not possible to tell accurately how representative it was of the Church of England as a whole. Statistical significance was promoted by the large samples in some cases, and effect sizes were generally modest. Future studies would benefit from more sensitive and robust instruments. There was no comparable measure of well-being prior to the pandemic, so the measure used here was of perceived change in well-being, rather than 
an absolute measure. Future studies of the effects of pandemics or other crises on churchgoers would benefit from a panel surveys that would allow well-being to be measured in the same subjects before and after the onset of a crisis.

\section{Conclusions}

This study has demonstrated that self-perceived changes in psychological wellbeing, as assessed by affect balance, varied during the first COVID-19 lockdown in 2020 among a sample of 4449 churchgoers from the Church of England. It has extended earlier work on clergy by using a different measure of well-being, including lay people, and testing for the effects of personality and contextual variables. Psychological well-being was promoted by preference for feeling over thinking in the psychological type judging process, being older, belonging to the Evangelical wing of the Church and living in rural areas. Psychological well-being was lowered among people with a general tendency toward neuroticism, among those with an Epimethean (SJ) psychological temperament, among Anglo-Catholics, among those living in inner cities, among clergy, and among those with children under 13. Some of these findings may have arisen from the particular nature of the COVID-19 crisis and the ensuing lockdown, but some suggest more fundamental dispositions that might respond in a similar fashion to any sudden mass social crisis. The mitigating effects of relevant support were evident for both clergy and lay people, and a key finding was that it was those sources of support that were least often rated highly that may have had the strongest positive effects on well-being, particularly on those groups where well-being was lowest. This suggests that attending to these sources of support for relevant groups in a crisis may pay off best in terms of promoting psychological well-being among religious people.

\section{Compliance with Ethical Standards}

Conflict of interest No conflicts of interest were reported by the authors.

Ethical Approval Ethical approval was granted by the Research Ethics Committee for the School of Humanities, Religion and Philosophy ay York St John University (approval code: HRP-RS-AV-04-20-01). All participants had to affirm they were 18 or over and give their informed consent by clicking a box that gave access to the rest of the survey.

\section{References}

Alford, N. (2020). Lockdown as an introvert's paradise? Not quite. Retrieved 15 December 2020 from https://theboar.org/2020/10/lockdown-introverts-paradise-not-quite/.

Berg, A. (2020). Covid is affecting introverts and extroverts very differently. Just ask my wife. Retrieved 14 December 2020 from https://www.nbcnews.com/think/opinion/covid-impactingintroverts-extroverts-very-differently-just-ask-my-wife-ncna1246865. 
Bradburn, N. M. (1969). The structure of psychological well-being. Aldine.

Church of England. (2020a). Guidance on mental health and wellbeing and Coronavirus. https:// www.churchofengland.org/sites/default/files/2020-03/Guidance\%20on\%20mental\%20health\% 20 and $\% 20$ wellbeing\%20and\%20Coronavirus.pdf.

Church of England. (2020b). Wellbeing of clergy and lay ministers during the coronavirus pandemic. https://www.churchofengland.org/sites/default/files/2020-04/Wellbeing\%20of\%20clergy\% 20and\%201ay\%20ministers\%20during\%20the\%20coronavirus\%20pandemic.pdf.

Counted, V., Pargament, K. I., Bechara, A. O., Joynt, S., \& Cowden, R. G. (2020). Hope and wellbeing in vulnerable contexts during the COVID-19 pandemic: Does religious coping matter? The Journal of Positive Psychology. https://doi.org/10.1080/17439760.2020.1832247

Dein, S., Loewenthal, K., Lewis, C. A., \& Pargament, K. I. (2020). COVID-19, mental health and religion: An agenda for future research. Mental Health, Religion and Culture, 23(1), 1-9. https://doi. org/10.1080/13674676.2020.1768725

Denham, J. (2020). For introverts, lockdown is a chance to play to our strengths. The Guardian. https://www.theguardian.com/lifeandstyle/2020/may/02/for-introverts-lockdown-is-a-chance-toplay-to-our-strengths.

Duffy, J. (2020). Why lockdown is heaven for introverts like me. https://www.scotsman.com/news/ opinion/columnists/why-lockdown-heaven-introverts-me-jim-duffy-3019045.

Eysenck, H. J., \& Eysenck, M. W. (1985). Personality and individual differences: A natural science approach. New York: Plenum Press.

Eysenck, S. B. G., Eysenck, H. J., \& Barrett, P. (1985). A revised version of the psychoticism scale. Personality and Individual Differences, 6(1), 21-29. https://doi.org/10.1016/0191-8869(85) 90026-1

Francis, L. J. (2005). Faith and psychology: Personality, religion and the individual. London: Darton, Longman \& Todd.

Francis, L. J., Brown, L. B., \& Philipchalk, R. (1992). The development of an abbreviated form of the revised: Eysenck personality questionnaire (EPQR-A) Its use among students in England, Canada the USA and Australia. Personality and Individual Differences, 13(4), 443-449. https:// doi.org/10.1016/0191-8869(92)90073-X

Francis, L. J., Butler, A., Jones, S. H., \& Craig, C. L. (2007). Type patterns among active members of the Anglican Church: A perspective from England. Mental Health, Religion and Culture, 10(5), 435-443. https://doi.org/10.1080/13694670600668382

Francis, L. J., Edwards, O., \& ap Sion, T. (2020). Applying psychological type and psychological temperament theory to the congregations at cathedral carol services. Mental Health, Religion and Culture,. https://doi.org/10.1080/13674676.2020.1764516

Francis, L. J., \& Jones, S. H. (2000). The relationship between the Myers-Briggs Type Indicator and the Eysenck Personality Questionnaire among adult churchgoers. Pastoral Psychology, 48(5), 377-386. https://doi.org/10.1023/A:1022036504232

Francis, L. J., Kaldor, P., Robbins, M., \& Castle, K. (2005a). Happy but exhausted? Work-related psychological health among clergy. Pastoral Sciences, 24(2), 101-120.

Francis, L. J., Robbins, M., \& Astley, J. (2005b). Fragmented faith? Exposing the fault-lines in the Church of England. New York: Paternoster Press.

Francis, L. J., Robbins, M., \& Craig, C. (2011a). The psychological type profile of Anglican churchgoers in England: Compatible or incompatible with their clergy? International Journal of Practical Theology, 15(2), 243-259. https://doi.org/10.1515/IJPT.2011.036

Francis, L. J., \& Village, A. (Under review). Introducing The Index of Balanced Affect Change (TIBACh): A study among Church of England clergy and laity. Mental Health, Religion and Culture.

Francis, L. J., Village, A., Bruce, D., \& Woolever, C. (2015). Testing the balanced affect model of clergy work-related psychological health: Drawing on the U.S. Congregational Life Survey. In A. Village \& R. W. Hood (Eds.), Research in the social scientific study of Religion (Vol. 26, pp. 123-140). London: Brill.

Francis, L. J., Village, A., Robbins, M., \& Wulff, K. (2011b). Work-related psychological health among clergy serving in the Presbyterian Church (USA): Testing the idea of balanced affect. Review of Religious Research, 53(1), 9-22. https://doi.org/10.1007/s13644-011-0003-8

Francis, L. J., Village, A., \& Voas, D. (2018). Stress levels among Anglican clergy: The beneficial effects of feeling supported. Journal of Empirical Theology, 31(2), 265-287. https://doi.org/10.1163/15709 256-12341374 
Furnham, A. (1996). The big five versus the big four The relationship between the Myers-Briggs type indicator (MBTI) and NEO-PI five factor model of personality. Personality and Individual Differences, 21(2), 303-307. https://doi.org/10.1016/0191-8869(96)00033-5

Furnham, A., Eysenck, S. B. G., \& Saklofske, D. H. (2008). The Eysenck personality measures: Fifty years of scale development. In G. J. Boyle, G. Matthews, \& D. H. Saklofske (Eds.), Personality theory and assessment (Vol. 2 Personality measurement and testing, pp. 199-218). London: Sage.

Furnham, A., Jackson, C. J., Forde, L., \& Cotter, T. (2001). Correlates of the Eysenck personality profiler. Personality and Individual Differences, 30(4), 587-594.

Groarke, J. M., Berry, E., Graham-Wisener, L., McKenna-Plumley, P. E., McGlinchey, E., \& Armour, C. (2020). Loneliness in the UK during the COVID-19 pandemic: Cross-sectional results from the COVID-19 Psychological Wellbeing Study. PLoS ONE, 15(9), e0239698. https://doi.org/10.1371/ journal.pone.0239698

Hou, T., Zhang, T., Cai, W., Song, X., Chen, A., Deng, G., \& Ni, C. (2020). Social support and mental health among health care workers during Coronavirus Disease 2019 outbreak: A moderated mediation model. PloS ONE, 15(5), e0233831.

Jung, C. G. (1971). Psychological types: The collected works (Vol. 6). London: Routledge and Kegan Paul.

Keirsey, D. (1998). Please understand me II: Temperament, character and intelligence. Quebec: Prometheus Nemesis.

Keirsey, D., \& Bates, M. (1978). Please understand me (3rd ed.). Quebec: Prometheus Nemesis.

Kendall, E. (1998). Myers-Briggs type indicator: Step 1 manual supplement. New York: Consulting Psychologists Press.

Kluth, A. (2020). For introverts, quarantine can be a liberation. Bloomberg Opinion. https://www.bloom berg.com/opinion/articles/2020-03-28/coronavirus-for-introverts-quarantine-can-be-a-liberation.

Lockley, P. (2020). Incarnational ministry is desk-based, for now. Church Times. https://www.churc htimes.co.uk/articles/2020/9-april/comment/opinion/incarnational-ministry-is-desk-based-for-now.

Marshall, L., Bibby, J., \& Abbs, I. (2020). Emerging evidence on COVID-19's impact on mental health and health inequalities. https://www.health.org.uk/news-and-comment/blogs/emerging-evide nce-on-covid-19s-impact-on-mental-health-and-health.

McCrae, R. R., \& Costa, P. T. (1989). Reinterpreting the Myers-Briggs type indicator from the perspective of the five-factor model of personality. Journal of Personality, 57(1), 17-40. https://doi.org/10. 1111/j.1467-6494.1989.tb00759.x

McGowan, A. (2020). Communion and pandemic. Journal of Anglican Studies, 18(1), 2-8. https://doi. org/10.1017/S1740355320000285

Mental Health Foundation. (2020). Coronavirus: Mental Health in the Pandemic. The Mental health Foundation. Retrieved 14 December from https://www.mentalhealth.org.uk/our-work/research/ coronavirus-mental-health-pandemic.

Mind. (2020, 2 December). Coronavirus and your wellbeing. Retrieved 15 December 2020 from https:// www.mind.org.uk/information-support/coronavirus/coronavirus-and-your-wellbeing/

Myers, I. B., McCaulley, M. H., Quenk, N. L., \& Hammer, A. L. (1998). MBTI manual: A guide to the development and use of the Myers-Briggs Type Indicator (3rd ed.). Palo Alto: Consulting Psychologists Press.

O’Connor, D. B., Aggleton, J. P., Chakrabarti, B., Cooper, C. L., Creswell, C., Dunsmuir, S., Fiske, S. T., Gathercole, S., Gough, B., Ireland, J. L., Jones, M. V., Jowett, A., Kagan, C., Karanika-Murray, M., Kaye, L. K., Kumari, V., Lewandowsky, S., Lightman, S., Malpass, D., ... Armitage, C. J. (2020a). Research priorities for the COVID-19 pandemic and beyond: A call to action for psychological science. British Journal of Psychology, 111(4), e12468. https://doi.org/10.1111/bjop.12468

O'Connor, R. C., Wetherall, K., Cleare, S., McClelland, H., Melson, A. J., Niedzwiedz, C. L., O'Carroll, R. E., O’Connor, D. B., Platt, S., Scowcroft, E., Watson, B., Zortea, T., Ferguson, E., \& Robb, K. A. (2020b). Mental health and well-being during the COVID-19 pandemic: Longitudinal analyses of adults in the UK COVID-19 Mental Health and Wellbeing study. The British Journal of Psychiatry. https://doi.org/10.1192/bjp.2020.212

ONS. (2020). Coronavirus and the social impacts on Great Britain: 11 December 2020. London: United Kingdom Government Office for National Statistics (ONS). https://www.ons.gov.uk/peoplepopu lationandcommunity/healthandsocialcare/healthandwellbeing/bulletins/coronavirusandthesocialim pactsongreatbritain/11 december2020\#impacts-on-life-and-well-being-of-adults-experiencing-someform-of-depression-or-anxiety. 
Pirutinsky, S., Cherniak, A. D., \& Rosmarin, D. H. (2020). COVID-19, mental health, and religious coping among American Orthodox Jews. Journal of Religion and Health, 59(5), 2288-2301. https://doi. org/10.1007/s10943-020-01070-z

Public Health England. (2020). Guidance for the public on the mental health and wellbeing aspects of coronavirus (COVID-19). Public Health England. Retrieved 15 December from https://www.gov.uk/ government/publications/covid-19-guidance-for-the-public-on-mental-health-and-wellbeing/guida nce-for-the-public-on-the-mental-health-and-wellbeing-aspects-of-coronavirus-covid-19.

Ruisoto, P., Ramírez, M. R., García, P. A., Paladines-Costa, B., Vaca, S. L., \& Clemente-Suárez, V. J. (2021). Social Support Mediates the Effect of Burnout on Health in Health Care Professionals [Original Research]. Frontiers in Psychology. https://doi.org/10.3389/fpsyg.2020.623587

Schultz, M. F. (2020). Who's ready for coronavirus? Introverts. Washington Examiner. https://www.washi ngtonexaminer.com/opinion/whos-ready-for-coronavirus-introverts.

Singh, J. A. (2020). Introverts haven't had it much better than extroverts. Retrieved 15 December 2020 from https://www.livemint.com/opinion/columns/introverts-haven-t-had-it-much-better-than-extro verts-11594309488917.html.

Steele, R. S., \& Kelly, T. J. (1976). Eysenck Personality Questionnaire and Jungian Myers-Briggs type indicator correlation of extraversion-introversion. Journal of Consulting and Clinical Psychology, 44(4), 690-691.

Thomas, J., \& Barbato, M. (2020). Positive religious coping and mental health among Christians and Muslims in response to the COVID-19 pandemic. Religions, 11(10), 498-511.

Travers, M. (2020). Are extroverts suffering more from the quarantine? Not so fast, says new research. Retrieved 15 December 2020 from https://www.forbes.com/sites/traversmark/2020/04/30/are-extro verts-suffering-more-from-the-quarantine-not-so-fast-says-new-research/\#3541bac951a0.

Village, A. (in press). Testing the factor structure of the Francis Psychological Type Scales (FPTS): A replication among Church of England clergy and laity. Mental Health, Religion and Culture. https:// doi.org/https://doi.org/10.1080/13674676.2020.1780575

Village, A. (2016). Biblical conservatism and psychological type. Journal of Empirical Theology, 29(2), 137-159. https://doi.org/10.1163/15709256-12341340

Village, A. (2018). The Church of England in the first decade of the 21st century: The Church Times Surveys. Palgrave Macmillan. https://www.palgrave.com/gb/book/9783030045272.

Village, A., \& Francis, L. J. (in press-a). Churches and faith: Attitude towards church buildings during the 2020 Covid-19 lockdown among churchgoers in England. Ecclesial Practices. https://ray.yorksj.ac. uk/id/eprint/4990/

Village, A., \& Francis, L. J. (in press-b). Wellbeing and perceptions of receiving support among Church of England clergy during the 2020 COVID-19 pandemic. Mental Health, Religion and Culture. https://www.tandfonline.com/toc/cmhr20/current

Village, A., Payne, J. V., \& Francis, L. J. (2018). Testing the balanced affect model of clergy work-related psychological health: Replication among Anglican clergy in Wales. Rural Theology, 16(2), 93-100.

Wei, M. (2020). Social distancing and lockdown — an introvert's paradise? An empirical investigation on the association between introversion and the psychological impact of COVID19-related circumstantial changes [Original Research]. Frontiers in Psychology, 11, 2440. https://doi.org/10.3389/fpsyg. 2020.561609

White, R. G., \& Van Der Boor, C. (2020). Impact of the COVID-19 pandemic and initial period of lockdown on the mental health and well-being of adults in the UK. BJPsych Open, 6(5), e90. https://doi. org/10.1192/bjo.2020.79

Williams, S. N., Armitage, C. J., Tampe, T., \& Dienes, K. (2020). Public perceptions and experiences of social distancing and social isolation during the COVID-19 pandemic: a UK-based focus group study. British Medical Journal Open, 10(7), e039334. https://doi.org/10.1136/bmjopen-2020-039334

Publisher's Note Springer Nature remains neutral with regard to jurisdictional claims in published maps and institutional affiliations. 